\title{
IMPACT OF LAND USE PRACTICES ON GREENHOUSE GAS EMISSIONS FROM AGRICULTURE LAND ONORGANIC SOILS
}

\author{
Ieva Licite, Ainars Lupikis \\ Latvian State Forest Research Institute "Silava", Latvia \\ ieva.licite@silava.lv, ainars.lupikis@silava.lv
}

\begin{abstract}
Greenhouse gas emissions (carbon dioxide, methane, nitrous oxide) from managed organic soils in cropland and grassland is significant part of greenhouse gas (GHG) emission profile of Latvia. Total area of organic soils in grassland and cropland in Latvia is around $8 \%$, but GHG emissions from this area constitute more than $30 \%$ of the total agricultural GHG emissions (data vary by GHG inventory years and soil data set used). GHG emission measurement data characterizing different agricultural land use practices can support the most appropriate choice of organic soil management that contributes less to the total GHG emission amount. Within the scope of the LIFE REstore project "Sustainable and responsible management and re-use of degraded peatlands in Latvia" research was carried out to assess impact of the management practices to GHG emissions from agricultural land on organic soils. GHG gases from agricultural land were measured in two year cycle in permanent grassland and cropland sites. Ecosystem gas $-\mathrm{CO}_{2}, \mathrm{CH}_{4}$, and $\mathrm{N}_{2} \mathrm{O}-$ exchange measurements were done, using the opaque chamber method and the transparent chamber method. Research results demonstrate the net ecosystem exchange of GHG emissions in relation to different management practices in cropland and grassland on organic soils. Average $\mathrm{CO}_{2}$ emissions from cropland were $4.8 \mathrm{t} \mathrm{CO}_{2}-\mathrm{C} \mathrm{ha}^{-1}$, but from grassland $4.4 \mathrm{t}$ $\mathrm{CO}_{2}-\mathrm{C} \mathrm{ha}{ }^{-1}$. Study sites in cropland were sink of methane $-0.59 \mathrm{~kg} \mathrm{CH}_{4} \mathrm{C} \mathrm{ha}{ }^{-1}$, but source of methane in grassland $57.8 \mathrm{~kg} \mathrm{CH}_{4} \mathrm{C} \mathrm{ha}^{-1}$. Average $\mathrm{N}_{2} \mathrm{O}$ emissions from cropland were $7.1 \mathrm{~kg} \mathrm{~N}_{2} \mathrm{O}-\mathrm{N}$ ha ${ }^{-1}$, but from grassland $0.3 \mathrm{~kg} \mathrm{~N} \mathrm{~N}_{2} \mathrm{O}-\mathrm{N}$ ha $^{-1}$. Cumulative $\mathrm{GHG}$ emissions from organic soils on cropland and grassland show that cropland annually emits more $-20.8 \mathrm{t} \mathrm{CO}_{2} \mathrm{eq} \mathrm{ha}{ }^{-1}$ than grassland $-18.1 \mathrm{t} \mathrm{CO}_{2} \mathrm{eq} \mathrm{ha}^{-1}$ thus looking from GHG emission budget perspective, perennial grassland is more advisable for management of organic soils in agriculture.
\end{abstract}

Keywords: land use, greenhouse gas emissions, organic soil, agriculture.

\section{Introduction}

Distribution of organic soils in Europe is imbalanced with considerably higher concentration in the Northern part of Europe [1] Distribution is mainly determined by the climate conditions during the last 10000 years, including rainfall and temperature regime, higher summer temperatures and lower rainfall rates determine lower peatland distribution [2]. In the European Union countries peatlands cover $7.7 \%$ of total area and greenhouse gas emissions from managed peatlands in some countries reach more than one fifth of all emissions [3]. One of typical management practices of organic soils is agriculture.

Undisturbed peatland ecosystems may be effective carbon sequesters, globally peatlands contain approximately one third of global soil organic carbon [4]. Drainage and cultivation of peatlands may promote decomposition of previously stored organic material and consequently lead to increased carbon dioxide and nitrous oxide emissions while methane emissions decrease in aerobic circumstances [5] Historically peatlands were often drained for peat mining purposes and cutaway areas are under different after use scenarios including cropland and grassland management practices. In overall, agricultural usage of organic soils in Europe represents minor part of total area of organic soils, but greenhouse gas emissions from these soils contribute considerably to national greenhouse gas emission profiles [5].

In Latvia, the area of organic soils used for agricultural purposes is around $8 \%$ of total agricultural land area (depending on the data source used for calculations), but greenhouse gas emissions from this area is more than $30 \%$ of the total emissions from agricultural activities in the sectors of Agriculture and Land Use, Land Use Change and Forestry (LULUCF) according to the National Greenhouse Gas Inventory [6].

Considering the impact of greenhouse gas emissions, organic soil management in agriculture is potentially crucially important for policy makers to seek for the management practices that would be on low emission pattern, socially accepted and cost effective. One of the main obstacles for effective policy planning is lack of updated activity data and scarcity of knowledge about country specific GHG exchange data in cropland and grassland with organic soils. 
Greenhouse gas emissions from organic soils managed for agriculture are calculated in the National Inventory Report of GHG Emissions (NIR) under the United Nations Framework Convention on Climate Change (UNFCCC), the Kioto Protocol and Regulation (EU) No 525/2013 of the European Parliament and of the Council. Reporting in the European Union countries is done in accordance with the Intergovernmental Panel on Climate Change IPCC (2006) Agriculture, Forestry and Other Land Use (AFOLU) guidelines, usage of the IPCC (2014) Wetlands Supplement is encouraged. IPCC definition of organic soil largely follows the definition of Histosols by FAO, but in order to allow country specific definitions has omitted the thickness of the peat layer [7].

Annual GHG emissions and removals from organic soils used for agriculture in Latvia are calculated using the so-called Tier 1 method of the IPCC guidelines. The Tier 1 method is the simplest approach and annual GHG emissions are calculated by multiplying activity data (organic soil area) by default area based emission factors (EFs). EFs describe the net annual soil GHG emissions and removals and reflect impacts of ecosystem type, land management and environmental conditions [8]. Area of organic soils in cropland and grassland is determined by the National Forest Inventory [9].

In NIR submission 2019 Latvia uses default IPCC (2014) Wetlands Supplement EFs for drained organic soils $-7.9 \mathrm{t} \mathrm{CO}_{2}-\mathrm{C} \mathrm{ha}^{-1}$ for cropland (cropland drained, Boreal and Temperate), $6.1 \mathrm{t} \mathrm{CO}_{2-}$ $\mathrm{C} \mathrm{ha}^{-1}$ for grassland (grassland, deep-drained, nutrient rich, Temperate), $1165 \mathrm{~kg} \mathrm{CH}_{4} \mathrm{ha}^{-1}$ (deepdrained Grassland, Cropland, drainage diches), proportion of area of drainage ditchesin cropland and grassland $5 \%, 16 \mathrm{~kg} \mathrm{CH}_{4} \mathrm{ha}^{-1}$ (grassland, deep-drained, nutrient rich) $13 \mathrm{~kg} \mathrm{~N}_{2} \mathrm{O}-\mathrm{N} \mathrm{ha}^{-1}$ for cropland (boreal and temperate drained organic soil) and $8.2 \mathrm{~kg} \mathrm{~N}_{2} 0-\mathrm{N} \mathrm{ha}^{-1}$ for grassland (temperate organic soil, deep drained, nutrient rich) [6]. Deep drained factors are chosen because of the absence of national information about mean annual water table and/or land-use intensity [7].

Default EFs are mean values of annualized net emission and removal estimates that are compiled from available studies data and categorized by climate zones. If national data are available, countries may opt for usage of the Tier 2 method that incorporates country specific EFs or a model based approach (Tier 3). Usage of higher Tier method with country specific EFs increases accuracy of national estimates. Organic soils in cropland and grassland are among the key sources of GHG emissions in Latvia. In 2017 the total amount of GHG emissions from cultivation of organic soil in croplands and grasslands in the Agriculture sector constituted $25.8 \%$ of the total emissions from agriculture. The total amount of GHG emissions from organic soil in LULUCF sector corresponded to nearly $100 \%$ of the total emissions from croplands and grasslands in this sector [6]. Country specific data on net annual soil GHG emissions and removals in cropland and grassland management of organic soils are NEEded to allow more accurate GHG emission calculations, including possible stratification of more land use categories. More accurate GHG emission calculations promote better policy planning, considering possible management options.

The aim of the study is to acquire the net annual greenhouse gas exchange data from organic soils in cropland and grassland to verify country specific data against the default IPCC emission factors and to propose improved data for reporting of GHG emissions from organic soils in the National Greenhouse Gas Inventory.

\section{Materials and methods}

\section{Site selection and description}

Measurement sites in agricultural land were selected by using database of areas affected by peat extraction (LIFE REstore project data [10]) and the Land Parcel Information System data maintained by the State Support Service of Latvia.

Measurement sites representing the following agricultural land use and vegetation types were searched for selection:

1. perennial grassland (mown);

2. cropland (cultivated grass or crops).

Main sites selection criteria were lowered ground water table and highly decomposed fen or transitional mire peat. Potential sites were assessed from the physical accessibility point of view. Such sites were selected that could be reached by car throughout the whole year and whose centres were in no more than $300 \mathrm{~m}$ distance from the roadside. The random number selection method (random 
number generator in QGIS - function "Random selection within subsets") was used for the final selection of the sites. Agreements with landowners ensured permanence of the sites during the measurement period.

The location of the measurement sites and their coordinates in the LKS-92 system are shown in Table 1.

Table 1

Location of measurement sites

\begin{tabular}{|c|c|c|c|c|}
\hline \multirow{2}{*}{ Land use type } & \multirow{2}{*}{ Crop rotation } & \multirow{2}{*}{ Object } & \multicolumn{2}{|c|}{ Coordinates (LKS-92) } \\
\cline { 3 - 5 } & Pasture & Kašk̆u Mire & 474539 & Y \\
\hline \multirow{2}{*}{$\begin{array}{c}\text { Perennial grassland } \\
\text { on former peat } \\
\text { extraction sites }\end{array}$} & annually mowed grass & Stabulnieku I Mire & 672977 & 254237 \\
\cline { 2 - 5 } & annually mowed grass & Lielsala Mire & 399127 & 358300 \\
\cline { 2 - 5 } & hay production & Krista Mire & 667644 & 275163 \\
\hline \multirow{2}{*}{$\begin{array}{c}\text { Cropland on former } \\
\text { peat extraction sites } \\
\text { - rotational crops }\end{array}$} & maize / maize & SIA “Mārupe" & 496872 & 301104 \\
\cline { 2 - 5 } & cereal / legumes & Diervanīne Mire I & 684572 & 290033 \\
\cline { 2 - 5 } & cereal / fallow & Gavennpurs Mire & 414206 & 332834 \\
\hline
\end{tabular}

Cropland sites were established in integrated farming systems with crop rotations cereals/legumes, cereals/fallow, legume/legume and maize/maize. Agricultural management in the study sites was continued on business as usual base, including application of fertilizers.

\section{Study design}

GHG were measured monthly for two consecutive years from December of 2016 until December of 2018 in 5 measurement points (permanent plastic collar in the ground in each of the points) with a distance between points 10 to $15 \mathrm{~m}$ in each of the sample plot. Two methods were used for GHG measurements - manual autotrophic measurements with opaque closed chambers and air sampling $\left(\mathrm{CO}_{2}, \mathrm{CH}_{4}\right.$ and $\left.\mathrm{N}_{2} \mathrm{O}\right)$; manual ecosystem flux measurements with closed transparent chambers (only $\mathrm{CO}_{2}$ ). Transparent chambers were used only during April - October, when the air temperature is over $0{ }^{\circ} \mathrm{C}$ to measure photosynthetic $\mathrm{CO}_{2}$ uptake and ecosystem $\mathrm{CO}_{2}$ emissions under different lighting intensity $(25 \%, 50 \%$ and $100 \%$ shading). Opaque chambers were used throughout the year, also in winter.If the vegetation in the chambers was higher than the height of the chambers, then we used extensions - extension height is $50 \mathrm{~cm}$.

\section{Measurements with opaque chambers}

The volume of the opaque chambers is $65 \mathrm{~L}$ and the diameter $-40 \mathrm{~cm}$, and the chamber is made of white plastic material. Duration of every measurement campaign with opaque chambers was 60 minutes. Air samples were collected in vacuumed $100 \mathrm{ml}$ glass bottles $0,20,40$ and 60 minutes after the headspace is placed on the collar. The collected air samples were transported to laboratory and analysed by Shimadzu GC-2014 gas chromatograph.

\section{Measurements with transparent chambers}

We used an EGM-5 portable $\mathrm{CO}_{2}$ gas analyser to measure monthly $\mathrm{CO}_{2}$ fluxes in transparent chamber from the beginning of April until the end of October. Transparent chamber is made of organic glass and is $35 \mathrm{~cm}$ in height and $50 \mathrm{~cm}$ in diameter. The chamber is equipped with a cooling system, temperature sensors and photosynthetically active radiation (PAR) sensors. There are two tubes connected to the chamber for air outflow and inflow from the gas analyser. The same collars as for measurements with opaque chambers were used. The duration of measurement in each sample point was 150 seconds.

Additionally to GHG flux measurements, soil and water data were acquired in the measurement sites to detect parameters that can influence soil GHG emissions. Sampling was done with probes for undisturbed samples. Soil sample preparation and analyses were done according to the ICP Forests guidelines [11]. Soil analyses were done by the Latvian State Forest Research Institute "Silava" Forest Environment Laboratory. 


\section{Calculation of $\mathrm{CO}_{2}$ net ecosystem exchange}

Net Ecosystem Exchange (NEE) (from April to October) was modelled, using the $\mathrm{CO}_{2}$ flux data from the measurements with transparent chambers and EGM-5 and air temperature, ground water level and PAR as linear regression model parameters (1). Those variables were measured directly during field measurements. We used air temperature values and radiation measurements from closest-to-site meteorological towers (which had radiation measurements), and manual ground water measurements from ground water wells installed in the sites as variables for linear regression models. Linear regression models were created for each of the sites. In rest of the year (from November and December) $\mathrm{CO}_{2} N E E$ were calculated as mean ecosystem respiration, which was measured by opaque chambers and manual air sampling.

$$
N E E=a+a 1 \cdot \mathrm{T}+a 2 \cdot G W+a 3 \cdot P A R,
$$

where $T$ - air temperature during the measurements, ${ }^{\circ} \mathrm{C}$;

$G W$ - water table level below the ground surface, $\mathrm{cm}$;

$P A R$ - photosynthetically active radiation, umol $\mathrm{m}^{-2} \cdot \mathrm{s}^{-1}$.

Flux measurements include carbon captured by photosynthesis in crops which is later harvested, but not captured by flux measurements. When the biomass was harvested, carbon removed in biomass was included in calculations by adding it to the total $N E E$ as source of emissions. We used harvested crop yield to biomass ratio [12] model total carbon removed by harvesting.

\section{Calculation of $\mathrm{CH}_{4}$ and $\mathrm{N}_{2} \mathrm{O}$ net ecosystem fluxes}

Closed opaque chamber methods were used to collect data to estimate $\mathrm{CH}_{4}$ and $\mathrm{N}_{2} \mathrm{O}$ ecosystem fluxes. The yearly emissions are calculated as a sum of mean monthly values for each of the sites. If there were no data for some of the months due to errors, the gaps we filled by modelling $\mathrm{CH}_{4}$ emissions for the missing month. Soil temperature and ground water level were used as a model parameter to fill the missing values. In case of missing values for $\mathrm{N}_{2} \mathrm{O}$, monthly values were interpolated (average from previous and next month).

\section{Results and discussion}

The air temperature, PAR and the ground water level were significant factors influencing the $\mathrm{CO} 2$ flux rate and could explain $0.29 \%$ to $0.72 \%$ of total NEE shown in Table 2.The low accuracy of the linear regression model in SIA "Mārupe" (crop rotation - maize/maize) could be explained due to too low chamber height and it was not possible to cover the maize with the chamber without damaging the crops.

Table 2

Linear $N E E$ regression model and model parameters

\begin{tabular}{|c|c|c|c|c|c|}
\hline \multirow{2}{*}{ Object } & \multicolumn{4}{|c|}{ Parameters } & \multirow{2}{*}{$\boldsymbol{R}^{2}$} \\
\cline { 2 - 5 } & intercept & $\boldsymbol{a} 1$ & $\boldsymbol{a} 2$ & $\boldsymbol{a} 3$ & \\
\hline Kašk̆u Mire & -0.27 & 0.0729 & $0.856 .10^{-3}$ & $-1.63 .10^{-3}$ & 0.59 \\
\hline Stabulnieku I Mire & -1.16 & 0.113 & 0.0135 & $-1.50 .10^{-3}$ & 0.52 \\
\hline Lielsala Mire & -0.42 & 0.0398 & 0.0122 & $-1.47 .10^{-3}$ & 0.69 \\
\hline Krista Mire & -3.07 & 0.243 & 0.0281 & $-2.96 .10^{-3}$ & 0.72 \\
\hline SIA "Mārupe" & 0.27 & 0.0493 & $4.44 .10^{-3}$ & $-0.838 .10^{-3}$ & 0.29 \\
\hline Diervanīne Mire I & -0.87 & 0.105 & $2.49 .10^{-3}$ & $-1.53 .10^{-3}$ & 0.67 \\
\hline Gaveñpurs Mire & -0.65 & 0.0950 & $2.43 .10^{-3}$ & $-1.02 .10^{-3}$ & 0.40 \\
\hline Diervanīnes Mire II & 0.022 & 0.111 & $-6.00 .10^{-3}$ & $-1.95 .10^{-3}$ & 0.62 \\
\hline
\end{tabular}

Average annual net carbon dioxide emissions from cropland were $4.8 \mathrm{t} \mathrm{CO}_{2}-\mathrm{C} \mathrm{ha}^{-1}$, but from perennial grassland $4.4 \mathrm{t} \mathrm{CO}_{2}-\mathrm{C} \mathrm{ha}^{-1}$. This result in Table 3 coincides with the previous studies, indicating that organic soils used in agriculture for growing cereals and grasses in boreal and temperate climate zones (studies from Finland, Sweden and Netherland) are net emitters of $\mathrm{CO}_{2}$ and the fluxes range from 2.2 to $31 \mathrm{t} \mathrm{C} \mathrm{ha}^{-1} \cdot \mathrm{yr}^{-1}[5 ; 13 ; 14]$. After drainage, peat decomposition and mineralisation increase rapidly, causing $\mathrm{CO}_{2}$ emissions, $\mathrm{CO}_{2}$ uptake by photosynthesis cannot compensate ecosystem $\mathrm{CO}_{2}$ losses and net ecosystem exchange is positive. Study results compared 
with IPCC (2014) Wetlands Supplement $\mathrm{CO}_{2}$ EFs for drained organic soils, show lower net ecosystem exchange in the study sites. In one study site (Gavenpurs Mire) in cropland cereal production was followed by fallow that possibly impacted the particular result (decrease of emissions) because of biomass left in soil. Quite high variations among $\mathrm{CO}_{2}$ emissions reported in different studies may partly be explained with differences of grassland and cropland systems. Under grassland definition there can be intensively managed (fertilized) areas, as well as low-intensity grasslands [13].

Table 3

$\mathrm{CO}_{2}$-C net emissions

\begin{tabular}{|c|c|c|c|c|c|}
\hline \multirow{2}{*}{ Land use } & \multirow{2}{*}{ Site name } & \multirow{2}{*}{ Cultivation } & \multicolumn{3}{|c|}{ t $\mathrm{CO}_{2}-\mathrm{C}$ ha $^{-1}$ annually } \\
\hline & & & $1^{\text {st }}$ year & $2^{\text {nd }}$ year & Average \\
\hline grassland & Kašķu Mire & pasture & 5.19 & 4.63 & 4.91 \\
\hline grassland & Krista Mire & hay production & 3.81 & 8.42 & 6.12 \\
\hline grassland & Lielsala Mire & annually mowed grass & 2.30 & 1.65 & 1.98 \\
\hline grassland & Stabulnieku I Mire & annually mowed grass & 3.17 & 5.95 & 4.56 \\
\hline cropland & Diervanīnes Mire I & cereal/legumes & 6.05 & 4.19 & 5.12 \\
\hline cropland & Gavenpurs Mire & cereal/fallow & 5.44 & 2.66 & 4.05 \\
\hline cropland & SIA "Mārupe" & maize/maize & 4.06 & 4.78 & 4.42 \\
\hline cropland & Diervanīnes Mire II & legumes/legumes & 6.42 & 4.44 & 5.43 \\
\hline
\end{tabular}

Methane emissions tend to decrease after drainage. Soils can be sources as well as sinks of $\mathrm{CH}_{4}$ emissions. Well drained soils are quite often sinks of $\mathrm{CH}_{4}$ because of activity of methanotrophic bacteria that use $\mathrm{CH}_{4}$ for growth [15]. As shown in Table 4, the study sites in cropland were sink of methane (Table 4) - $0.59 \mathrm{~kg} \mathrm{CH}_{4} \mathrm{C} \mathrm{ha}^{-1}$ annually (from - 0.07 to $-1.26 \mathrm{~kg} \mathrm{CH}_{4} \mathrm{C} \mathrm{ha}^{-1}$ ), but source of methane in perennial grassland sites $57.8 \mathrm{~kg} \mathrm{CH}_{4} \mathrm{C} \mathrm{ha}^{-1}$ annually (from -0.76 to $-188.73 \mathrm{~kg} \mathrm{CH}_{4} \mathrm{C}$ per hectare). The reason of high methane emissions in Krista and Lielsalas mire was extremely high precipitation amount in 2017 ( $1^{\text {st }}$ year), when the annual rainfall was one of the highest since the beginning of meteorological observations followed by high ground water level. Findings from other researches in boreal and temperate zone reports annual fluxes of $\mathrm{CH}_{4}$ emissions from cropland and grassland management on organic soils in a range of $-3.7 \mathrm{~kg} \mathrm{CH}_{4}-\mathrm{C}$ ha ${ }^{-1}$ uptake to emission of $40 \mathrm{~kg} \mathrm{CH}_{4}-\mathrm{C} \mathrm{ha}^{-1}$ [15-18]. The study results compared with IPCC (2014) Wetlands Supplement $\mathrm{CH}_{4}$ EFs for drained organic soils, on average show higher net emissions in the study sites.

Table 4

$\mathrm{CH}_{4}-\mathrm{C}$ net emissions

\begin{tabular}{|c|c|c|c|c|c|}
\hline \multirow{2}{*}{ Land use } & Site name & Cultivation & \multicolumn{3}{|c|}{$\mathbf{k g ~ C H}_{\mathbf{4}}-\mathbf{C ~ h a}^{-1}$ annually } \\
\cline { 3 - 5 } & & & $\mathbf{1}^{\text {st }}$ year & $\mathbf{2}^{\text {nd }}$ year & Average \\
\hline grassland & Kašķu Mire & pasture & -0.61 & -0.90 & -0.76 \\
\hline grassland & Krista Mire & hay production & 343.48 & 33.97 & 188.73 \\
\hline grassland & Lielsala Mire & annually mowed grass & 58.51 & 12.25 & 35.38 \\
\hline grassland & Stabulnieku I Mire & annually mowed grass & 15.52 & 0.42 & 7.97 \\
\hline cropland & Diervanīn Mire I & cereal/legumes & 0.13 & -0.27 & -0.07 \\
\hline cropland & Gaveñpurs Mire & cereal/fallow & -0.61 & -0.40 & -0.51 \\
\hline cropland & SIA "Mārupe” & maize/maize & -0.35 & -0.71 & -0.53 \\
\hline cropland & Diervanīnes Mire II & legumes/legumes & -1.19 & -1.33 & -1.26 \\
\hline
\end{tabular}

There are constrains to obtain precise nitrous oxide emissions because of great sessional and annual variations [19], as well as the formation process of $\mathrm{N}_{2} \mathrm{O}$ emissions is complicated and still not entirely investigated. Scientific evidences show that non-growing season $\mathrm{N}_{2} \mathrm{O}$ emissions should not be ignored in EFs calculations, because inclusion of these emissions significantly impacts (increases) EFs [20]. Agricultural management in the study sites was continued on business as usual base, including regular application of fertilizers that is one of explanations of relatively high $\mathrm{N}_{2} \mathrm{O}$ emissions in cropland management practice sites $-7.1 \mathrm{~kg} \mathrm{~N}_{2} \mathrm{O}-\mathrm{N}$ ha ${ }^{-1}$ (from 1.95 to $16.80 \mathrm{~kg} \mathrm{~N}_{2} \mathrm{O}-\mathrm{N}$ ha ${ }^{-1}$ annually)and $0.3 \mathrm{~kg} \mathrm{~N}_{2} \mathrm{O}-\mathrm{N} \mathrm{ha}^{-1}$ (from -0.08 to $1.01 \mathrm{~kg} \mathrm{~N}_{2} \mathrm{O}-\mathrm{N} \mathrm{ha}^{-1}$ annually) for permanent grassland. The study results of $\mathrm{N}_{2} \mathrm{O}$ emissions are shown in Table 5. Annual numbers were impacted by significant rise in $\mathrm{N}_{2} \mathrm{O}$ emissions during the spring months. We observed seasonal impact on GHG 
emissions for $\mathrm{N} 2 \mathrm{O}$ emissions that during spring months well exceeded annual average. Similar impact is reported by several other studies $[17 ; 19 ; 21]$. Increased $\mathrm{N} 2 \mathrm{O}$ data collection frequency during spring and summer months could contribute to emission data precision.

On average, $\mathrm{N}_{2} \mathrm{O}$ emissions from the study sites fall into the flux range demonstrated in the previous studies of cropland and grassland on organic soils in temperate and boreal zone 2.0 to $11.0 \mathrm{~kg}$ $\mathrm{N}_{2} \mathrm{O}-\mathrm{N} \mathrm{ha}{ }^{-1} \cdot \mathrm{yr}^{-1}[19 ; 21 ; 22]$. The study results compared with IPCC (2014) Wetlands Supplement $\mathrm{N}_{2} \mathrm{O}$ EFs for drained organic soils, in the study sites show lower net ecosystem exchange.

Table 5

$\mathrm{N}_{2} \mathrm{O}-\mathrm{N}$ net emissions

\begin{tabular}{|c|c|c|c|c|c|}
\hline \multirow{2}{*}{ Land use } & \multirow{2}{*}{ Site name } & \multirow{2}{*}{ Cultivation } & \multicolumn{3}{|c|}{$\mathbf{k g ~ N}_{\mathbf{2}} \mathbf{O}-\mathbf{N} \mathbf{h a}^{\mathbf{- 1}}$ annually } \\
\cline { 3 - 6 } & & $\mathbf{1}^{\text {st }}$ year & $\mathbf{2}^{\text {nd }}$ year & Average \\
\hline grassland & Kašķu Mire & pasture & -0.13 & -0.02 & -0.08 \\
\hline grassland & Krista Mire & hay production & 1.10 & 0.91 & 1.01 \\
\hline grassland & Lielsala Mire & annually mowed grass & 0.01 & -0.02 & -0.01 \\
\hline grassland & Stabulnieku I Mire & annually mowed grass & 0.07 & 0.17 & 0.12 \\
\hline cropland & Diervanīn Mire I & cereal/legumes & 5.60 & 5.13 & 5.37 \\
\hline cropland & Gaveñpurs Mire & cereal/fallow & 0.22 & 3.68 & 1.95 \\
\hline cropland & SIA “Mārupe” & maize/maize & 17.97 & 15.63 & 16.80 \\
\hline cropland & Diervanīnes Mire II & legumes/legumes & 5.48 & 3.58 & 4.53 \\
\hline
\end{tabular}

Cumulative $\mathrm{GHG}$ emissions (expressed in $\mathrm{CO}_{2}$ equivalents) from organic soils on cropland and grassland show that cropland annually emits more $-20.8 \mathrm{t} \mathrm{CO}_{2}$ eq ha ${ }^{-1}$ than grassland $-18.1 \mathrm{t} \mathrm{CO}_{2}$ eq ha ${ }^{-1}$.

\section{Conclusions}

This study for the first time in Latvia provides country specific information on the net ecosystem exchange for different land use practices on organic soils in agriculture - permanent grassland and cropland. The net ecosystem $\mathrm{CO}_{2}$ exchange was $4.8 \mathrm{t} \mathrm{CO}_{2}-\mathrm{C} \mathrm{ha}^{-1}$ and $4.4 \mathrm{t} \mathrm{CO}_{2}-\mathrm{C}^{-1}{ }^{-1}$ for cropland and grassland respectively and these values are below IPCC default emission factor values currently used in the National GHG Inventory for LULUCF sector for drained organic soils. Similarly, the study results of fluxes of $\mathrm{N}_{2} \mathrm{O}\left(7.1 \mathrm{~kg} \mathrm{~N}_{2} \mathrm{O}-\mathrm{N} \mathrm{ha}^{-1}\right.$ from cropland and $0.3 \mathrm{~kg} \mathrm{~N}_{2} \mathrm{O}-\mathrm{N}$ ha ${ }^{-1}$ from grassland) are smaller to compare to IPCC default values, but the results of $\mathrm{CH}_{4}$ fluxes $\left(-0.59 \mathrm{~kg} \mathrm{CH}_{4}-\mathrm{C}^{-1}\right.$ ha from cropland and $57.8 \mathrm{~kg} \mathrm{CH}_{4} \mathrm{C} \mathrm{ha}^{-1}$ from grassland) exceed the IPCC default values as regards grassland. IPCC encourages countries to use country specific EFs, if available. We suggest introduction of EFs obtained by this study into the National GHG Emission Inventory.

Cumulative GHG net emissions from cropland $\left(20.8 \mathrm{t} \mathrm{CO}_{2}\right.$ eq ha $\left.{ }^{-1}\right)$ on organic soils exceed grassland emissions (18.1 $\mathrm{t} \mathrm{CO}_{2} \mathrm{eq} \mathrm{ha}^{-1}$ ). Looking from $\mathrm{GHG}$ emission budget perspective, perennial grassland is more advisable for management of organic soils in agriculture than cropland.

\section{Acknowledgements}

The study is done in the framework of the European Union LIFE Programme project "Demonstration of climate change mitigation potential of nutrient rich organic soils in Baltic States and Finland" (LIFE OrgBalt, LIFE18 CCM/LV/001158)", the study data were acquired within the scope of the European Union LIFE Programme project "Sustainable and responsible management and re-use of degraded peatlands in Latvia" (LIFE14 CCM/LV/001103, LIFE REstore).

\section{References}

[1] Tanneberger F., Tegetmeyer C., Busse S., Barthelmes A., Shumka S., Moles Mariné A., Jenderedjian K., Steiner G.M., Essl F., Etzold J. The peatland map of Europe. Mires and Peat, vol. 19, 2017, (Art. 22), pp.1-17.

[2] Joosten H., Tanneberger F., Moen A. (eds.) Mires and peatlands of Europe. Status, distribution and conservation. Schweizerbart Science Publishers, Stuttgart, 2017. 
[3] Buschmanna C., Rödera N., Berglundb K., Berglundb Ö., Lærkec P.E., Maddisond M., Manderd Ü., Myllyse M., Osterburgf B., van den Akkerg J.J.H., Perspectives on agriculturally used drained peat soils: Comparison of the socioeconomic and ecological business environments of six European Regions. Land use policy 90, 2020.

[4] Zicheng Y., Beilman D.W., Frolking S., MacDonald G.M., Roulet N.T., Camill P., Charman D.J. Peatlands and Their Role in the Global Carbon Cycle. Eos, vol. 92, No.12, 2011, pp. 97-98.

[5] Kasimir-Klemedtsson A., Klemedtsson L., Berglund K., Martikainen P., Silvola J., Oenema O., Greenhouse gas emissions from farmed organic soils: a review. Soil Use and Management 13, 1997, pp. 245-250.

[6] LEGMC, 2019: Latvia's National Inventory under the United Nations Framework Convention on Climate Change (UNFCCC), the Kyoto Protocol and Regulation (EU) No 525/2013 for 19902019.

[7] IPCC: 2013 Supplement to the 2006 IPCC Guidelines for National Greenhouse Gas Inventories: Wetlands, edited by: Hiraishi T., Krug T., Tanabe K., Srivastava N., Baasansuren J., Fukuda M., and Troxler T. G., IPCC, Switzerland, pp. 353. [online] [09.03.2020]. Available at: https://www.ipcc-nggip.iges.or.jp/public/wetlands/

[8] Jauhiainen J., Alm J., Bjarnadottir B., Callesen I., Christiansen J.R., Clarke N., Dalsgaard L., He H., Jordan S., Kazanavičiūte V., Klemedtsson L., Lauren A., Lazdins A., Lehtonen A., Lohila A., Lupokis A., Mander Ü., Minkkinen K., KasimirÅ., Olsson M., Ojanen P., Óskarsson H., Sigurdsson B. D., Søgaard G., Soosaar K., Vesterdal L., Laiho R. Reviews and syntheses: Greenhouse gas exchange datat from drained organic forest soils - a review of current approaches and recommendations for future research. Biogeosciences, 2019, pp. 1-17.

[9] PetajaG., Okmanis M., Polmanis K., Stola J., Spalva G., Jansons J. Evaluation of greenhouse gas emissions and area of organic soils in cropland and grassland in Latvia - integrated National forest inventory data and soil maps approach. Agronomy Research, 16(4), 2018, pp. 1809-1823.

[10] LIFE REstore projekta tiešsaistes datu bāze par kūdras ieguves ietekmētajām teritorijām (LIFE REstore project data base on degraded peatlands in Latvia). LIFE REstore project website, 2019. (In Latvian). [online] [16.03.2020]. Available at: https://restore.daba.gov.lv/public/lat/datu_baze1/

[11] Cools N., de Vos R. (Eds.). Part X Sampling and Analysis of Soil. In Manual on methods and criteria for harmonized sampling, assessment, monitoring and analysis of the effects of air pollution on forests. UNECE ICP Forests Programme Co-ordinating Centre, 2010, pp. 208.

[12] Palosuo T., Heikkinen J., Regina K. Method for estimating soil carbon stock changes in Finnish mineral cropland and grassland soils. Carbon management vol.6, 2016, pp. 207-2020.

[13] Elsgaard L., Gorres C. M., Hoffmann C.C., Blicher-Mathiesen G., Schelde K., Petersen S.O. Net ecosystem exchange of $\mathrm{CO} 2$ and carbon balance for eight temperate organic soils under agricultural management. Agriculture, Ecosystems and Environment 162, 2012, pp. 52-67.

[14] Gyldenkærne S., Münier B.E., Olesen J.E., Olesen S.E., Petersen B.M., Christensen B.T., Opgørelseaf CO2-emissioner frais alanvendelseogæn dringeriareal anvendelse LULUCF (Land Use, Land Use Change and Forestry) - Metode beskrivelse samt opgørelse for 1990-2003. Arbejdsrapportfra DMU, nr. 2132005, 2005, (in Danish with English summary).

[15] Kasimir-Klemedtsson A., Weslien P., Klemedtsson L. Methane and nitrous oxide fluxes from a farmed Swedish Histosol. European Journal of Soil Science 60, 2009, pp. 321-331.

[16] Maljanen M., Liikanen A., Silvola J., Martikainen P.J. Methane fluxes on agricultural and forested boreal organic soils. Soil Use Management 19, 2003a, pp. 73-79.

[17] Petersen S.O., Hoffmann C.C., Schafer C.-M., Blicher-Mathiesen G., Elsgaard L., Kristensen K., Larsen S.E., Torp S.B., Greve M.H. Annual emissions of $\mathrm{CH} 4$ and N2O, and ecosystem respiration, from eight organic soils in Western Denmark managed by agriculture. Biogeosciences 9, 2012, pp. 403-422.

[18] Regina K., Pihlatie M., Esala M., Alakukku L. Methane fluxes on boreal arable soils. Agriculture, Ecosystems and Environment 119, 2007, pp. 346-352.

[19] Regina K., Syvasalo E., Hannukkala A., Esala M. Fluxes of N2O from farmed peat soils in Finland. European Journal of Soil Science, 55 (3), 2004, pp. 591-599.

[20]Z Shang Z., Abdalla M., Kuhnert M., Albanito F., Zhou F., Xia L., Smith P. Measurement of $\mathrm{N}_{2} \mathrm{O}$ emissions over the whole year is necessary for estimating reliable emission factors. Environmental Pollution vol.259, 2020, Article number 113864. 
[21] Maljanen M., Liikanen A., Silvola, J. Martikainen P.J. Nitrous oxide emissions from boreal organic soil under different land-use. Soil Biology and Biochemistry 35, 2003b, pp. 689-700.

[22] Nykänen H., Alm J., Lang K., Silvola J. \&Martikainen P.J. Emissions of CH4, N2O and CO2 from a virgin fen and a fen drained for Grassland in Finland. Journal of Biogeography 22, 1995, pp. 351-357. 